\title{
FORMULATION AND COMPARATIVE EVALUATION OF ONDANSETRON HYDROCHLORIDE MOUTH DISSOLVING TABLETS IN INDIA
}

\author{
ABDUL RAHEEM T. ${ }^{*}$, RANJEET SINGH ${ }^{1}$, AISHWARYA HIREMATH ${ }^{1}$, SHASHANK NAYAK N. ${ }^{1}$, SHWETHA KAMATH K. S. ${ }^{1}$
}

1Department of Industrial Pharmacy, Bapuji Pharmacy College, SS layout, Shamnur Road, Davanagere 577004

Email: armuthu96@gmail.com

Received: 29 Apr 2019 Revised and Accepted: 30 Jul 2019

\begin{abstract}
Objective: The aim of the present study was to prepare the ondansetron hydrochloride Mouth Dissolving Tablets (MDTs) followed by its comparison with ethical and non-ethical (generic) marketed tablets.

Methods: Prior to the formulation, drug excipient compatibility study was carried out by FTIR spectroscopy. The $\lambda_{\text {max }}$ was determined by UV spectroscopy. The ondansetron hydrochloride MDTs were prepared by direct compression method using Sodium Starch Glycolate (SSG) as super disintegrant and camphor as a sublimating agent. Then the prepared MDTs were subjected to evaluation of post compression parameters such as thickness and diameter, weight variation, wetting time, hardness, friability, disintegration and dissolution. The results obtained were compared with that of ethical and non-ethical marketed ondansetron hydrochloride $4 \mathrm{mg}$ tablets.
\end{abstract}

Results: The $\lambda_{\max }$ was found at $310 \mathrm{~nm}$. FTIR study revealed that excipients used in the prepared formulations are compatible with the drug. The thickness and diameter was in the range of 2.646 to $3.27 \mathrm{~mm}$ and 6.0 to $8.12 \mathrm{~mm}$, respectively. Friability was in the range of 0.43 to $0.88 \%$ and had a slightly higher friability (1.27\%) for sublimated tablets. Wetting time and disintegration time were in the range of 15 to 40 sec and 23 to 50 sec, respectively. The $100 \%$ drug release was found within $180 \mathrm{sec}$ for all the codes. These results were then compared with non-ethical film coated ondansetron marketed tablets.

Conclusion: Ondansetron hydrochloride MDT $4 \mathrm{mg}$ tablets prepared in the laboratory were under specified IP limits. The experimental findings demonstrated that any of these ethical and non-ethical tablets of ondansetron hydrochloride can be selected, advised by the physician or pharmacist, as per the patient's need and economical status.

Keywords: Hardness, Friability, Disintegration, Dissolution, Ondansetron hydrochloride, Mouth dissolving tablets, FTIR spectroscopy, Quality control tests, Post compression parameters, MDT

(C) 2019 The Authors. Published by Innovare Academic Sciences Pvt Ltd. This is an open access article under the CC BY license (http://creativecommons.org/licenses/by/4.0/) DOI: http://dx.doi.org/10.22159/ijpps.2019v11i9.33840

\section{INTRODUCTION}

Oral administration of tablets is still the best choice of method to treat various disorders over several novel drug delivery systems [1]. Among oral route administrations, fast dissolving drug delivery system is more suitable when comparing to the conventional means due to the patients convenience [2]. MDT disintegrates within seconds in patient's mouth and therefore used in the condition of dysphasia [3].

Ondansetron hydrochloride is chemically 9-methyl-3-[(2-methyl1H-imidazol-1-yl)methyl]-2,3,4,9-tetrahydro-1H-carbazol-4-one hydrochloride selective serotonin receptor blocker (5 hydroxy tryptamine type 3) which is used as an antiemetic in the cancer chemotherapy $[2,4]$

For testing the quality of a finished tablet product, evaluation parameters such as hardness, friability, disintegration time, and dissolution profile study are more precise since it reflects the therapeutic effectiveness and bioavailability of the drug [5]. Some of the studies showed dissimilar results in post compression parameters among different marketed products that contain same active pharmaceutical ingredients [6-8]. In some conditions tablets with same drug or drug content may not be giving a same therapeutic response, which may be due to the different rate and extent of absorption, varying purity of the drug, and by using various types of excipients etc. [9-11]. These reports demonstrate the importance of comparative study of different marketed products with the same active ingredients.

The availability of numerous brands of ondansetron hydrochloride MDT in the drug market makes clinicians and pharmacists difficult to select a suitable brand or the possibility of alternative use. Prescribing physicians should also develop awareness regarding the interchangeability of multisource branded generic drug products.
Despite the considerable use in India, there are no reports on the comparative study of various brands of ondansetron hydrochloride MDT tablets marketed in India; hence the present investigation has been carried out. In this study an attempt has been made to compare the different evaluation parameters like thickness and diameter, weight variation, wetting time, hardness, friability, disintegration time, and dissolution profile of ethical and non-ethical marketed tablets of ondansetron hydrochloride with tablets prepared in the laboratory.

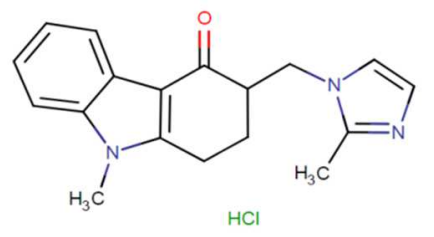

Fig. 1: Chemical structure of ondansetron hydrochloride

\section{MATERIALS AND METHODS}

\section{Materials}

Ondansetron hydrochloride pure drug was received from Zydus Cadila Ltd. Ondansetron hydrochloride MDT $4 \mathrm{mg}$ was prepared in the laboratory by using SSG as superdisintegrant and camphor as a sublimating agent. According to the availability of ondansetron hydrochloride $4 \mathrm{mg}$, four ethical and one non ethical tablets were purchased from a local pharmacy and Janaushadhi Store, Davangere, India respectively during Feb-2019. The different tablets are listed in table 1 . All chemical reagents used $(0.1 \mathrm{~N} \mathrm{HCl}$, methylene blue and distilled water) were of analytical grade. 
Table 1: List of ondansetron $4 \mathrm{mg}$ tablets

\begin{tabular}{lll}
\hline Code & Name & Manufacturer \\
\hline A & Vomikind ${ }^{\circledR}-$ MD 4 & Mankind Pharma Ltd \\
B & Vomiros-4MD ${ }^{\circledR}$-MD 4 & Roussel ${ }^{\circledR}$ Laboratories Pvt Ltd \\
C & Ondem ${ }^{-M}$ MD & Alkem Health Sciences \\
D & Onvin-4 MD & Rivpra Formulation Pvt Ltd \\
E & Ondansetron hydrochloride MDT 4 mg (Superdisintegrants) & Prepared in Laboratory \\
F & Ondansetron hydrochloride MDT 4 mg (Sublimation) & Prepared in Laboratory \\
\hline
\end{tabular}

\section{Preparation of tablets by direct compression method}

\section{By using superdisintegrant (Code E)}

Accurately weighed quantities of ingredients except lubricating agent were mixed in a mortar and pestle for 10 min to get a uniform blend. The uniform blend passed through sieve no.60.
Magnesium stearate was added as lubricating agent. Tablets were prepared by direct compression method using $6 \mathrm{~mm}$ flat punches on a 10 station rotary compression machine(Rimek Nanikadi, Gujarat) $[12,13]$. The formula was obtained by performing trial and error method and best-fit formula was selected as shown in table 2.

Table 2: Formulation for code $\mathrm{E}$

\begin{tabular}{lc}
\hline Ingredients & Formula \\
\hline Ondansetron hydrochloride & $4.0 \mathrm{mg}$ \\
Sodium starch glycolate & $6.0 \mathrm{mg}$ \\
Microcrystalline cellulose & $37.0 \mathrm{mg}$ \\
Mannitol & $45.0 \mathrm{mg}$ \\
Talc & $5.0 \mathrm{mg}$ \\
Magnesium stearate & $3.0 \mathrm{mg}$ \\
\hline
\end{tabular}

\section{By sublimation technique (Code F)}

Accurately weighed quantity of ondansetron hydrochloride, sublimating agent (camphor), and crospovidone were mixed in mortar and pestle and passed through the sieve no 60. Magnesium stearate and talc were added as lubricating agent. The tablets were prepared by direct compression method using $6 \mathrm{~mm}$ punches on a 10 station rotary compression machine. The prepared tablets were heated in a hot air oven at $60{ }^{\circ} \mathrm{C}$ until it attains a constant weight (complete removal of volatilizable component camphor). Heating causes the evaporation of camphor leaving behind pores on the surface of the tablet, which causes faster disintegration of the tablet compared to conventional mouth dissolving tablet $[14,15]$. The formula was obtained by performing trial and error method and best-fit formula was selected as shown in table 3 .

Table 3: Formulations for code F

\begin{tabular}{ll}
\hline Ingredients & Formula \\
\hline Ondansetron hydrochloride & $4 \mathrm{mg}$ \\
Crospovidone & $9 \mathrm{mg}$ \\
Camphor & $4 \mathrm{mg}$ \\
Lactose & $74 \mathrm{mg}$ \\
Magnesium stearate & $4 \mathrm{mg}$ \\
Talc & $5 \mathrm{mg}$ \\
\hline
\end{tabular}

\section{Determination of absorption maxima of ondansetron hydrochloride}

Standard solution of $12 \mu \mathrm{g} / \mathrm{ml}$ ondansetron hydrochloride was prepared and scanned in the range of $400-200 \mathrm{~nm}$ by taking $0.1 \mathrm{~N}$
$\mathrm{HCl}$ as blank. The linearity plot was constructed by preparing the standard solution of drug in between $4-24 \mu \mathrm{g} / \mathrm{ml}$, where the drug obeys beer's lamberts law [16]. The absorbance for the respective concentration is depicted in table 4 .

Table 4: Data for standard plot of ondansetron hydrochloride in $0.1 \mathrm{~N} \mathrm{HCl}$

\begin{tabular}{llll}
\hline S. No. & Concentration $(\boldsymbol{\mu g} / \mathbf{m l})$ & Absorbance & Standard deviation (n=3) \\
\hline 1 & 0 & 0 & 0 \\
2 & 4 & 0.145 & \pm 0.127 \\
3 & 8 & 0.281 & \pm 0.095 \\
4 & 12 & 0.44 & \pm 0.048 \\
5 & 16 & 0.58 & \pm 0.097 \\
6 & 20 & 0.73 & \pm 0.062 \\
7 & 24 & 0.85 & \pm 0.091 \\
\hline
\end{tabular}

\section{Drug-excipient compatibility study}

Compatibility studies of ondansetron hydrochloride pure drug and formulations are performed by using fourier transform infrared spectroscopy (BrukerAlpha FTIR, Bruker). $\mathrm{KBr}$ disc method was used for the analysis and the spectra of the samples were obtained in the range of 4000 to $500 \mathrm{~cm}^{-1}$.

\section{Evaluation of post compression parameters}

All codes of tablets were subjected to the following quality control tests.

\section{Thickness and diameter}

Tablet was kept in between two arms of a digital micrometer for measuring the thickness and diameter. The procedure was repeated for 5 tablets and the average value was calculated [17].

\section{Weight variation}

20 tablets of each brands and generic were weighed individually using digital electronic balance (Shimadzu, Kyoto, Japan) and the average weight was calculated from the total weight. The percentage 
deviations from the mean value were calculated by using the following equation [18-20].

$$
\text { Weight variation }=[(\mathrm{W} 1-\mathrm{W} 2) / \mathrm{W} 2] \times 100 \% \text {. }
$$

Where, $\mathrm{W}_{1}=$ Initial weight of the tablet

$\mathrm{W}_{2}=$ Average weight of the tablet

According to official guidelines, $\pm 10 \%$ is permitted for tablets weighing $80 \mathrm{mg}$ or less. For tablets weighing $80-250 \mathrm{mg}$ and above $250 \mathrm{mg}, \pm 7.5 \%$ and $\pm 5 \%$ are acceptable respectively [7].

\section{Wetting time}

Five circular tissue papers of $10 \mathrm{~cm}$ diameter were placed in a petridish with a $10 \mathrm{~cm}$ diameter. Ten $\mathrm{ml}$ of water containing methylene blue, a water-soluble dye, was added to the petridish. A tablet was carefully placed on the surface of the tissue paper and the time required for water to reach the upper surface of the tablet was noted as a wetting time [21].

\section{Friability}

Friability testing is carried out to check how much mechanical stress can be tolerated by the tablets during its manufacturing, distribution, and handling. The instrument used to determine the friability is called Friabilator or friability tester. 10 tablets were weighed and placed in the friability test apparatus EF2-USP. The apparatus was operated for $4 \mathrm{~min}$ ie., 100 rotations $(25 \mathrm{rpm})$ and the tablets remained intact were weighed and recorded [22]. For calculating $\%$ friability, the equation given below was used. Friability less than $1 \%$ is considered as acceptable [23-26].

$\%$ Friability $=[($ Initial weight - Final weight $) /($ Initial weight $)] \times 100 \%$

\section{Hardness}

The resistance of a tablet for chipping and breakage while transporting can be measured by testing its hardness [27]. Thehardness of the tablet was tested using Monsanto hardness tester (Sheetal scientific industries, Ahmedabad) and expressed in terms of $\mathrm{kg} / \mathrm{cm}^{2}$. A tablet was placed vertically in between the spindle and anvil on the Monsanto hardness tester and the pointer on the reading were set to zero. Then the pressure was applied slowly in order to break the tablet and the reading was noted. The same procedure was followed for 10 tablets and the average of pressure required to break each tablet was recorded [28].

\section{Disintegration time}

The in vitro disintegration were carried out by electro lab digital tablet disintegration tester ED-2L. 6 tablets from each code were placed in 6 tubes of the basket and disc were placed above the tablet in order prevent the escape of the tablets from the tubes while operating. The assembly then dipped in one litre beaker filled with $700 \mathrm{ml}$ of distilled water and maintained the temperature at $37 \pm 0.5$
${ }^{\circ} \mathrm{C}$. The basket moved up and down around 5 to $6 \mathrm{~cm}$ vertically and the time at which the tablets completely pass through the sieves was recorded [12, 29].

\section{Dissolution studies}

In vitro dissolution studies were carried out by using the tablet dissolution tester (USP XX III), shown in fig. 2. Paddle type apparatus was used in accordance with USP specifications [30]. The dissolution medium of $900 \mathrm{ml}$ of $0.1 \mathrm{~N} \mathrm{HCl}(\mathrm{PH} \mathrm{1.2}$ ) was transferred to the basket and temperature was maintained at $37 \pm 0.5{ }^{\circ} \mathrm{C}$ [27]. After reaching the bath temperature and basket temperature $37 \pm 0.5{ }^{\circ} \mathrm{C}$, a tablet was placed in the basket and the paddle made to rotate at $50 \mathrm{rpm}$. Aliquots of $5 \mathrm{ml}$ were collected at an interval of 30,60, 90, 120, 150, and $180 \mathrm{sec}$ respectively by replacing pre-warmed dissolution medium to $37 \pm 0.5^{\circ} \mathrm{C}$. The drug concentration was analysed by UV spectrophotometer at $310 \mathrm{~nm}$.

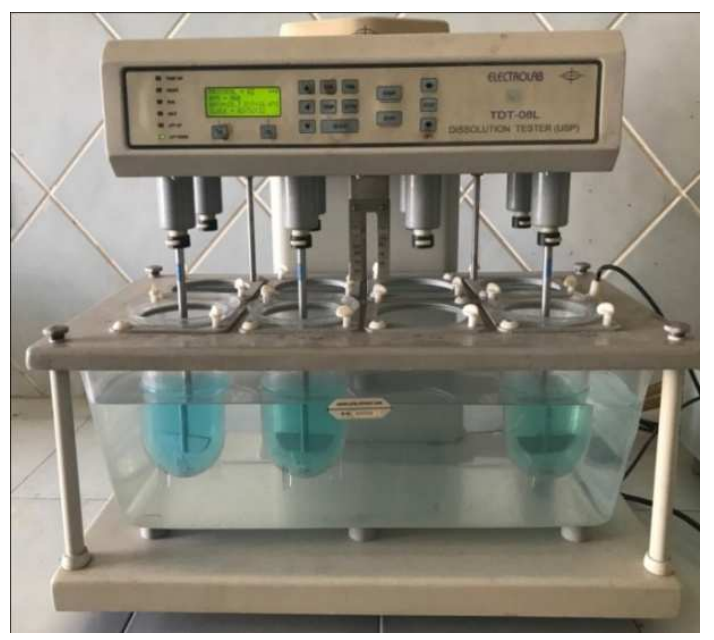

Fig. 2: Dissolution apparatus USP-XXIII (Electro lab, Mumbai)

\section{RESULTS AND DISCUSSION}

\section{Absorption maxima of ondansetron hydrochloride}

Standard plot of ondansetron hydrochloride is shown in fig. 3 . The linearity was observed in the range of $4-24 \mu \mathrm{g} / \mathrm{ml}$ with a correlation coefficient of 0.999 . The maximum absorbance of ondansetron hydrochloride was detected at $249 \mathrm{~nm}$ and depicted in fig. 4. It is observed that $310 \mathrm{~nm}$ can also be selected as $\lambda$ max since there was no much difference found in the absorbance value. There are more literatures available with $310 \mathrm{~nm}$; hence it is selected for this study [31-35].

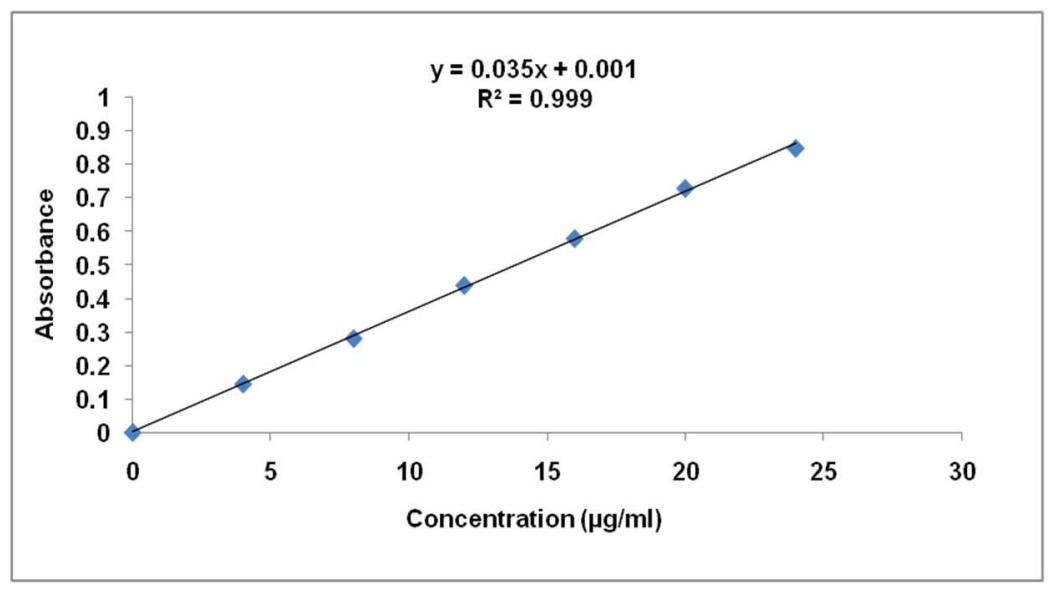

Fig. 3: Standard plot of ondansetron hydrochloride in $0.1 \mathrm{~N} \mathrm{HCl}$ at $310 \mathrm{~nm}$ 


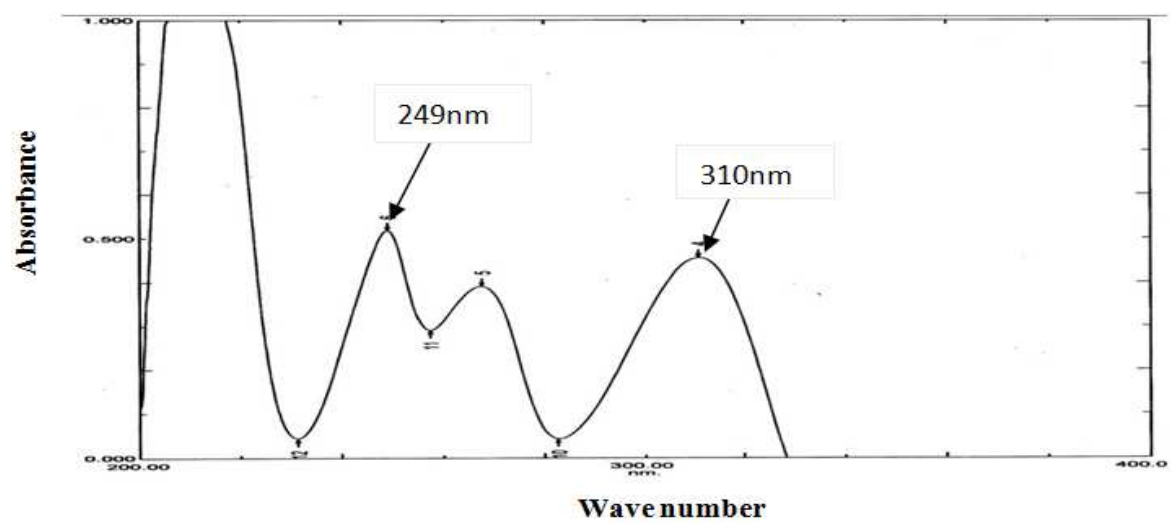

Fig. 4: UV spectrum of ondansetron hydrochloride

\section{Drug-excipient compatibility study}

Compatibility studies of ondansetron hydrochloride with other ingredients in both the formulations of code F and G were separately studied prior to the formulation of tablets. The FTIR spectrum obtained for ondansetron hydrochloride and the data are shown in fig. 5 and table 5 respectively. The bands of ondansetron hydrochloride pure drug matched with that of the standard IR spectrum of ondansetron hydrochloride given in literature reveals the purity of the drug. All the characteristic peaks of ondansetron hydrochloride in pure form were present in the spectrum of both the formulations as shown in fig. 6 and 7 respectively. It indicated there was no interaction between the drug and excipient in both the formulations; hence compatibility was confirmed.

Table 5: FTIR spectrum of pure ondansetron hydrochloride

\begin{tabular}{llll}
\hline S. No. & Bond (stretching) & Wave number $\mathbf{c m}^{-1} \mathbf{)}$ \\
\cline { 3 - 3 } & & Literature value [31] & 3478.42 \\
1 & $\mathrm{~N}-\mathrm{H}$ & $3000-3700$ & 1692.09 \\
2 & $\mathrm{C}=\mathrm{O}$ & $1600-1900$ & 1622.73 \\
3 & $\mathrm{C}=\mathrm{N}$ & $1600-1900$ & 1455.25 \\
4 & $\mathrm{C}-\mathrm{H}$ & $1300-1500$ & 912.81 \\
5 & $\mathrm{C}-\mathrm{C}$ & $800-1200$ & \\
\hline
\end{tabular}

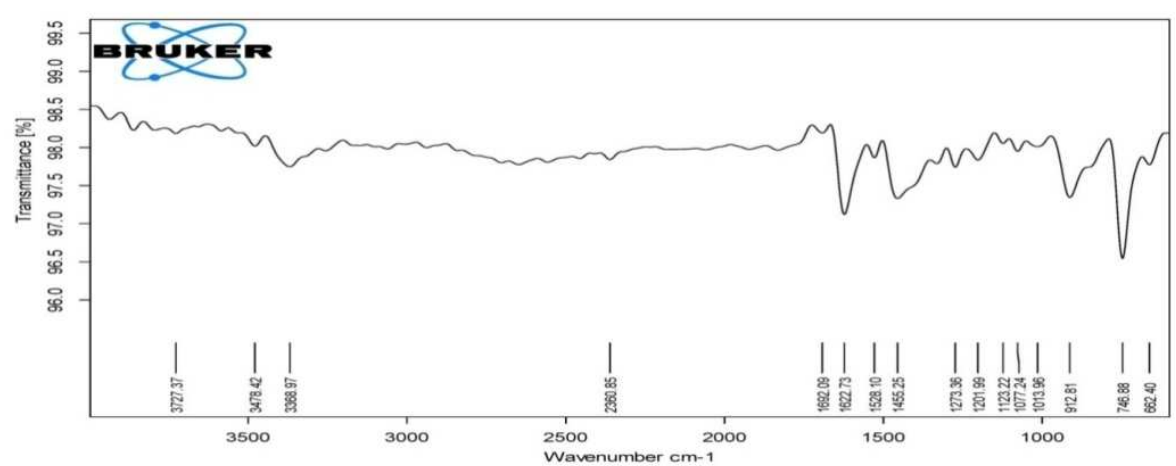

Fig. 5: FTIR spectrum of pure ondansetron hydrochloride

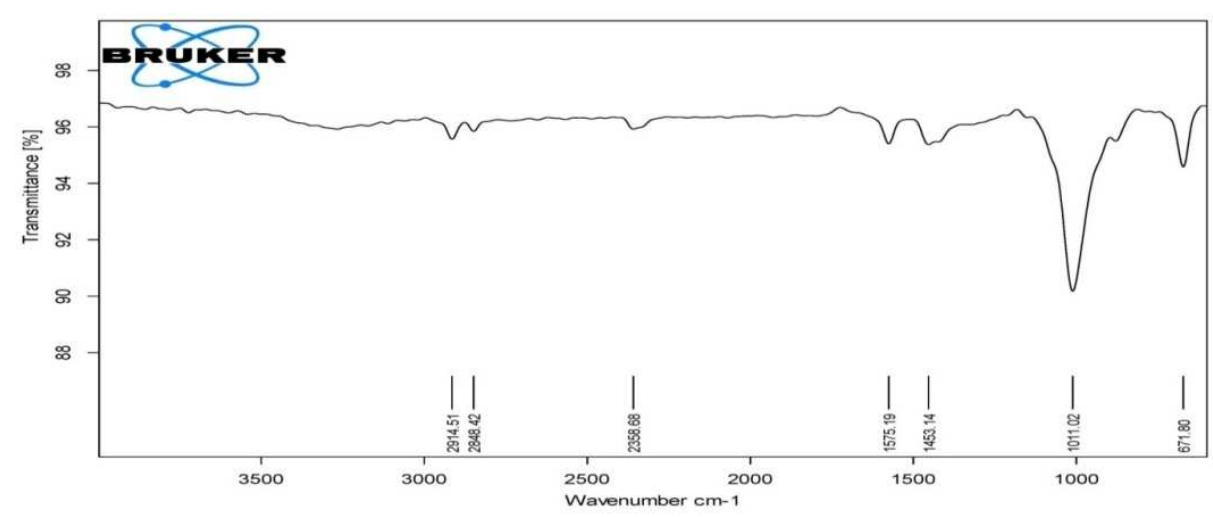

Fig. 6: FTIR spectrum of formulation code F 


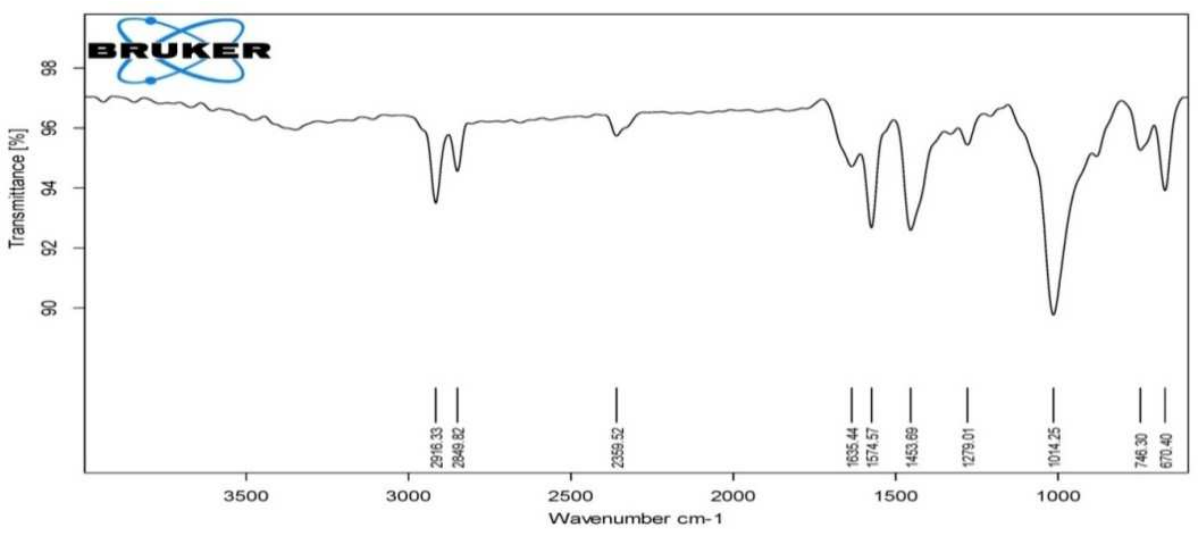

Fig. 7: FTIR spectrum of formulation code G

\section{Thickness and diameter}

The thickness and diameter of all the tablets lie between 2.646 to $3.27 \mathrm{~mm}$ and 6 to $8.12 \mathrm{~mm}$, respectively. The very minor deviations in the thickness and diameter, which reveals the proper operation and weighing of the powder blend during tablet manufacture.

\section{Weight variation}

All codes of tablets were passed the weight variation test (table 7) according to official guidelines since the percentage deviation was under $\pm 7.5 \%$. The uniformity of the weight implies proper tooling of the tablet punching machine.

Table 6: Data of thickness and diameter of ondansetron hydrochloride MDTs

\begin{tabular}{lll}
\hline Code & Thickness & Diameter \\
\hline A & $3 \pm 0.071$ & $7 \pm 0.052$ \\
B & $2.9 \pm 0.005$ & $8.12 \pm 0.008$ \\
C & $2.646 \pm 0.071$ & $6.5 \pm 0.015$ \\
D & $2.72 \pm 0.084$ & $6.97 \pm 0.012$ \\
E & $3.27 \pm 0.010$ & $6 \pm 0.007$ \\
F & $2.998 \pm 0.411$ & $6 \pm 0.009$ \\
\hline
\end{tabular}

mean $\pm S D, n=5$

Table 7: Weight variation studies of ondansetron hydrochloride MDTs

\begin{tabular}{|c|c|c|c|c|}
\hline S. No. & Code & Average of 20 tablets & Percentage deviation & Inference \\
\hline 1 & $\mathrm{~A}$ & 102.1 & 1.37 & Passes \\
\hline 2 & B & 166.05 & 1.275 & Passes \\
\hline 3 & $\mathrm{C}$ & 97.15 & 1.380 & Passes \\
\hline 4 & $\mathrm{D}$ & 115.2 & 1.056 & Passes \\
\hline 5 & $\mathrm{E}$ & 103.05 & 2.089 & Passes \\
\hline 6 & $\mathrm{~F}$ & 102.1 & 1.586 & Passes \\
\hline
\end{tabular}

\section{Wetting time}

All codes of tablets were wetted within $40 \mathrm{sec}$ (table 8); indicates the congenial porosity of the tablets. Further it enhances quick dissolution and disintegration. Fig. 8 represents the wetting time of code E.

\section{Friability}

The friability of various codes of tablets is shown below in table 9. A perusal to table 9 indicated that all codes of tablets, except code $\mathrm{F}$, are less than $1 \%$ ensures mechanical stability. Code $\mathrm{F}$ tablets were prepared in the laboratory by sublimation technique. It is observed that the pores formed by sublimation of camphor in code $\mathrm{F}$ tablets may be the reason to get higher friability value more than $1 \%$. For them, additional care should be taken in order to prevent mechanical stress during processing, handling, and transportation.

\section{Disintegration time}

The disintegration time of all codes, except E, was passable according to USP where mouth dissolving tablets have disintegration time standard value as low as $30 \mathrm{sec}$ (table 10).

Table 8: Wetting time data of ondansetron hydrochloride MDTs

\begin{tabular}{lll}
\hline S. No. & Code & Wetting time (sec) \\
\hline 1 & A & 15 \\
2 & B & 24 \\
3 & C & 14 \\
4 & D & 15 \\
5 & E & 40 \\
6 & F & 26 \\
\hline
\end{tabular}


Table 9: Friability data of ondansetron hydrochloride MDTs

\begin{tabular}{lllll}
\hline Code & Weight of 10 tablets & Difference in & \% Friability \\
\cline { 2 - 4 } & Before test $\mathbf{W}_{\mathbf{1}}$ & After test $\mathbf{W}_{\mathbf{2}}$ & 0.009 & 0.88 \\
$\mathrm{~A}$ & 1.018 & 1.009 & 0.01 & 0.60 \\
$\mathrm{~B}$ & 1.650 & 1.640 & 0.005 & 0.51 \\
$\mathrm{C}$ & 0.983 & 0.978 & 0.005 & 0.43 \\
$\mathrm{D}$ & 1.155 & 1.150 & 0.008 & 0.77 \\
$\mathrm{E}$ & 1.039 & 1.031 & 0.013 & 1.27 \\
$\mathrm{~F}$ & 1.026 & 1.013 & & \\
\hline
\end{tabular}

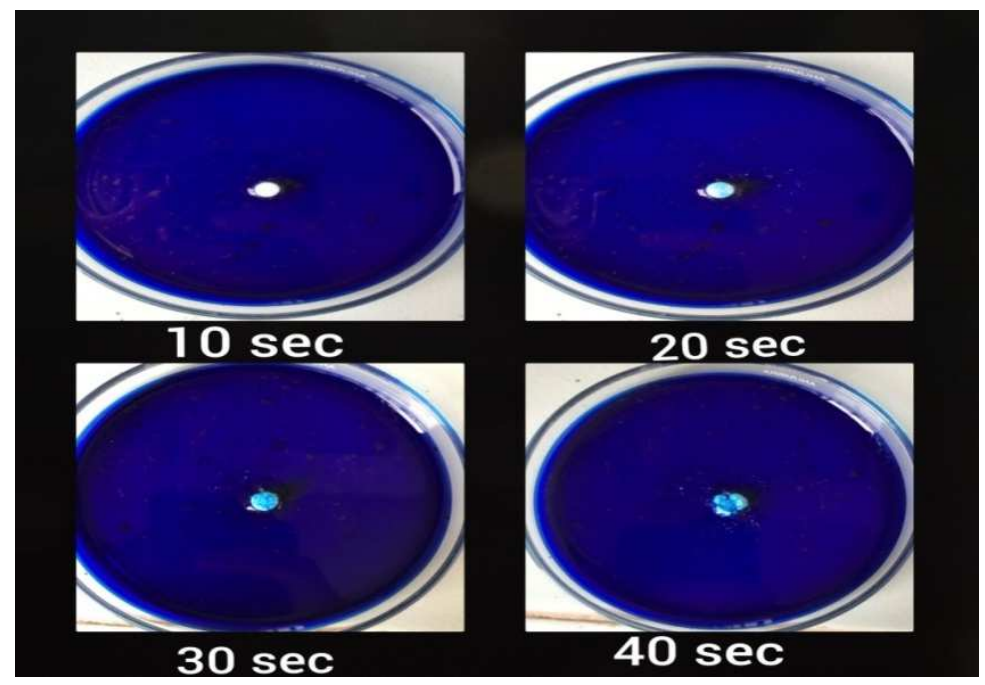

Fig. 8: Wetting time of code $E$

Table 10: Disintegration time data of studies of ondansetron hydrochloride MDTs

\begin{tabular}{lll}
\hline S. No. & Code & Disintegration time (sec) \\
\hline 1 & A & 23 \\
2 & B & 25 \\
3 & C & 20 \\
4 & D & 28 \\
5 & E & 35 \\
6 & F & 26 \\
\hline
\end{tabular}

\section{Hardness}

Perusal to table 11, it was found that poor hardness of all the codes of tablets. It may be due to the poor flow properties of the powder, air entrapment, and moisture content of the powder. But it can be tolerated since the tablets should be disintegrated within 1 min after placing it on the tongue [36]. The less hardness of the MDTs may be due the less compression force, which make the fast disintegration of a tablet [37]. Code D tablets have shown the highest hardness $\left(2.94 \mathrm{~kg} / \mathrm{cm}^{2}\right)$ among all the codes of tablets.

\section{Dissolution studies}

Dissolution profiles of the tablets are shown in fig. 9. Code A tablets had shown a faster release of $100.93 \%$ at 120 sec. When compared to all other codes of tablets, Code $\mathrm{F}$ tablets released slowly but within the limits ( $3 \mathrm{~min}$ ) as specified in IP [3]. Hence all the codes of tablets are within the official prescribed limits.

Comparison of ondansetron MDT $4 \mathrm{mg}$ with Non ethical ondansetron $4 \mathrm{mg}$ tablets

The generic ondansetron hydrochloride $4 \mathrm{mg}$ tablets obtained from the Janaushadhi Store, Davangere was film coated. It had an average weight of 144.14 with a percentage deviation of $1.23 \%$, which was acceptable. Friability of the tablets was less $(0.34 \%)$ when compared to other ethical tablets. The tablet disintegrated within 3 min and the time required for wetting was $58 \mathrm{sec}$. The hardness $\left(4.11 \pm 0.2079 \mathrm{~kg} / \mathrm{cm}^{2}\right)$ of the tablets was acceptable and high when compared to the ethical tablets. $99.5 \pm 0.6250 \%$ (in $40 \mathrm{~min}$ ) of the drug released was within the official limit.

Table 11: Hardness ondansetron hydrochloride MDTs

\begin{tabular}{lll}
\hline S. No. & Code & Hardness $\left.\mathbf{( k g} / \mathbf{c m}^{2}\right)$ \\
\hline 1 & A & $0.97 \pm 0.216$ \\
2 & B & $1.28 \pm 0.103$ \\
3 & C & $1.05 \pm 0.151$ \\
4 & D & $2.94 \pm 0.135$ \\
5 & E & $1.69 \pm 0.185$ \\
6 & F & $1.23 \pm 0.170$ \\
\hline
\end{tabular}

mean $\pm S D, n=10$ 


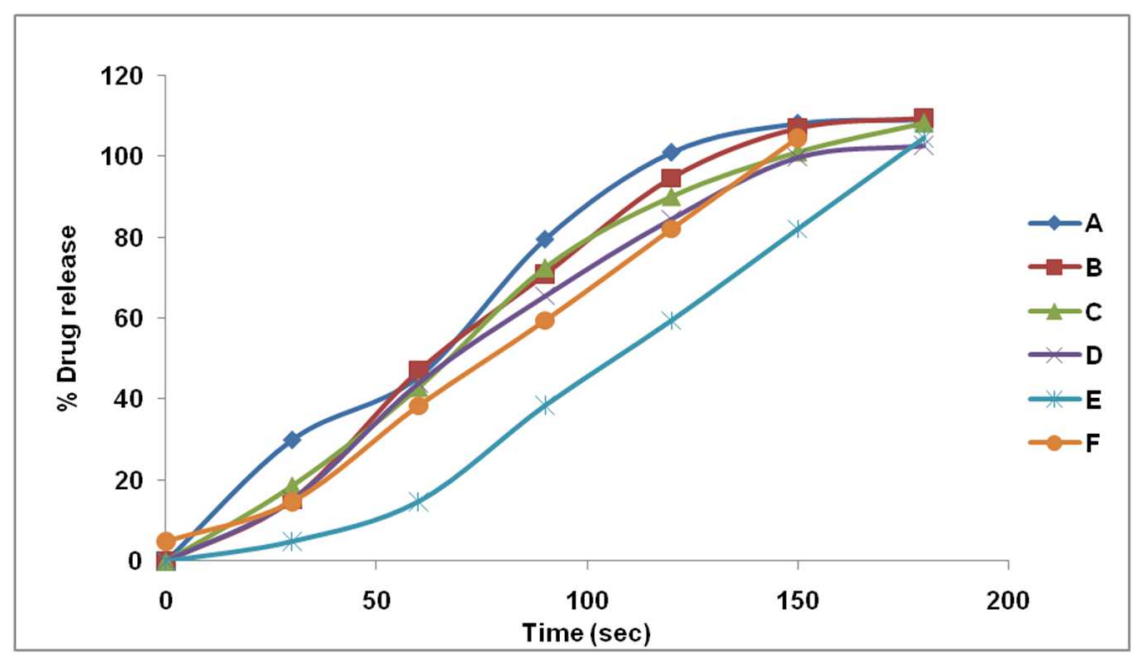

Fig. 9: Dissolution profile ondansetron hydrochloride MDTs

\section{CONCLUSION}

Ondansetron hydrochloride MDT $4 \mathrm{mg}$ tablets were prepared in the laboratory and it was under specified IP limits. The experimental findings demonstrated that any of these ethical and non-ethical tablets of ondansetron hydrochloride can be prescribed by the physician, as per the patient's needs. The film coated marketed tablet (Janaushadh) was compared with other ethical and formulated tablets and various parameters were evaluated and compared. The ethical and formulated tablets results were on the upper edge in comparison to film coated tablets. It is further suggested that post-marketing scrutiny like bioavailability studies must be performed for formulated and marketed ondansetron hydrochloride MDTs so as to ensure their safety, efficacy, and bioequivalence.

\section{ACKWNOLEDGEMENT}

We are thankful to Bapuji Pharmacy College, Davangere for providing all the necessary facilities to do the work.

\section{AUTHORS CONTRIBUTIONS}

Abdul Raheem. T, Ranjeet Singh, and Aishwarya Hiremath have performed the experiments, and wrote the manuscript. Dr. Shashank Nayak N designed the work, supervised, and edited the manuscript. Assistant Prof. Shwetha Kamath KS has helped to interpret the data using MS EXCEL.

\section{CONFLICT OF INETEERSTS}

The authors declare no conflict of interest

\section{REFERENCES}

1. Sateesh KV, Karthik N. Lovastatin fast dissolving tablets: Formulation and in vitro evaluation. Appl Sci Report 2015;11:76-82.

2. Rakesh KB, Pradip KG. Design and development of ondansetron orally disintegrating tablets and its optimization using design of experiment. Int J Pharm Sci Res 2012;3:840-7.

3. Dahiwal SS, Bhokare SG. In vitro evaluation of marketed brands of paracetamol tablets in india using quality control tests. Int J Pharm Pharm Res 2017;10:182-92.

4. Menaka M, Pandey VP, Anton SA. Colloidal dispersions as a potential nasal drug delivery system for ondansetron hydrochloride-in vitro and in vivo properties. Asian J Pharm Clin Res 2014;7:72-5.

5. Maria ER, Maria GV. Biopharmaceutical relevance of dissolution profile comparison: proposal of a combined approach. Dissolution Technologies 2014;2:32-43.

6. Wubayehu K, Ayenew A. Comparative quality evaluation of some metronidazole tablets and metronidazole benzoate oral suspensions available in retail outlets of Addis Ababa, Ethiopia. Int J Pharm Sci Res 2013;4:1384-91.
7. Abdullah AR, Tariqul I, Sazaul MS, Faruk H. Comparative study on quality analysis on marketed diclofenac sodium tablets of different brands available in Bangladesh. Res J Life Sci Bioinform Pharm Chem Sci 2018;4:362-73.

8. Esimone CO, Okoye FBC, Onah BU, Nworu CS, Omeje EO. In vitro bioequivalence study of nine brands of artesunate tablets marketed in Nigeria. J Vector Borne Dis 2008;45:60-5.

9. Anupam R, Orodispersible tablets: a review. Asian J Pharm Clin Res 2016;9:19-26.

10. Neelima RT, Lalitha KCT, Mallikarjun RB, Brahma RDR. Comparitive in vitro evaluation of different commercially available brands of pantoprazole tablets. Int J Pharm Sci Res 2012;3:1108-11.

11. Akira F, Norio YF, Taku N, Takenori N, Manabu S, Yasushi S, et al. Comparative in vivo bioequivalence and in vitro dissolution of two valproic acid sustained-release formulations. Drug Des Devel Ther 2008;2:139-44.

12. Sravanthi M, Srinivasa RB. Design and evaluation of ondansetron fast disintegrating tablets using natural polymers and modified starches as super disintegrants for the enhancement of dissolution. J Young Pharm 2017;9:519-24.

13. Shahtalebi MA, Tabbakhian M, Koosha S. Formulation and evaluation of orally disintegrating tablet of ondansetron using natural superdisintegrant. J HerbMed Pharmacol 2015;4:102-9.

14. Ashwini D, Darshak KP. Formulation and evaluation of orally disintegrating tablets of ondansetron hydrochloride by sublimation technique. Int J Biopharm 2014;5:163-70.

15. Dhaval MR, Shwetha SKK, Shashank NN, Arpit SP, Shabaraya AR. Effect of natural superdisintegrants on the fast dissolving tablet of carvedilol by sublimation method. Am J Pharm Tech Res 2013;3:259-70.

16. Sudhakararao GV, Sujana K, Pedababu T. Development and validation of uv spectrophotometric method for the estimation ofondansetron in bulk and pharmacutical formulation. W J Pharm Res 2014;3:2222.

17. Harshal P, Chhaya V, Pravin J, Kavita M. Development and evaluation of orodispersible tablets using a natural polysaccharide isolated from cassia tora seeds. Integr Med Res 2014;3:91-8.

18. Farzana $\mathrm{H}$, Sharja $\mathrm{N}$, Hasib AH, Shamima N. Comparative bioequivalence study of different brands of valsartan tablets marketed in bangladesh by dissolution modeling and quality control tests. W J Pharm Pharm Sci 2017;6:112-21.

19. Rakshita AS, Shashank NN, Shwetha S, Kamath K. Study of post compression parameters of various marketed paracetamol tablets in India. PharmaTutor 2019;7:35-42.

20. Ronald P, Shashank NN, Shwetha SKK, Shabaraya AR. Formulation and evaluation of fast dissolving tablets of flunarizine hydrochloride by sublimation method using sodium starch glycolate as superdisintegrant. Int J Pharm Tech Res 2014;6:1085-95. 
21. Oby D, Sharifa S, Shohag H. In vitro comparative quality evaluation of different brands of esomeprazole tablets available in selected community pharmacies in Dhaka, Bangladesh. BMC Res Notes 2018;11:1-5.

22. Promit D, Sajan D, Rumana A, Sumaiya H, Raushanara A, Mohammad S. Comparative in vitro equivalence evaluation of some spironolactone generic tablets, commercially available in Bangladesh drug market. Indo Am J Pharm Res 2017;7:544-51.

23. Shwetha SKK, Shashank NN, Srinivas H, Shabaraya AR. Design and evaluation of fast dissolving tablet of caffeine by using natural superdisintegrant. Inventi Rapid: Pharm Tech; 2013. p. 1-4.

24. Shashank NN, Shwetha SKK, Arpit SP, Srinivas H, Shabaraya AR. Formulation and evaluation of fast dissolving tablet of caffeine by sublimation method. Inventi Rapid: Pharm Tech; 2013. p. 1-4.

25. Mohammad S, Mohammad S, Bijja S, Ashraf B. Evaluation of tablets by friability apparatus. Int J Res Pharm Chem 2014;4:837-40.

26. Raghavendra RNG, Sanjeeva NB, Santhosh KB, Kistayya C. Design and development of taste masked oral disintegrating tablet of ondansetron hydrochloride. Res J Pharm 2017;7:5864.

27. Sunidhi M, Shivali S, Sachin G, Bhimi K, Abhishek S. Formulation and evaluation of mouth dissolving tablets of ondansetron hydrochloride using plantago ovata (isapghula) mucilage as natural super disintegrating agent. Int J Pharm Sci Drug Res 2017;9:240-6

28. Anupam S, Vineet $\mathrm{K}$, Ankita G. Comparative in vitro evaluation of four different brands of metformin $\mathrm{HCl}$ available in Kanpur district, India. Der Pharm Lett 2016;8:419-24.
29. Arpit SP, Shashank NN, Shwetha SKK, Dhaval MR, Shabaraya AR. Design development and evaluation of fast dissolving tablets of loratadine by direct compression method. Am J PharmTech Res 2013;3:1-14.

30. The United States pharmacopeia. National formulary. Vol. 1. Rockville (MD): United States Pharmacopeial Convention: Collodion; 2017.

31. Siraj NS, Band A, Abdul R, Khan GJ. Formulation optimization and evaluation of gastroretentive tablets of ondansetron $\mathrm{HCl}$. J Drug Delivery Ther 2018;8:185-95.

32. Anirudh SP, Harish G, Pragath KB, Debjit B, Duraivel S. Effect of super disintegrants on formulation of ondansetron HCL immediate release tablets by direct compression method. Int J Pharm Clin Res 2012;4:61-7.

33. Rajnikant MS, Narendra PC, Digesh DS. Formulation and evaluation of fast dissolving tablets of ondansetron by solid dispersion in superdisintegrants. Indian J Pharm Edu Res 2013;47:49-55

34. Shyam RS, Bhupendra KP, Uttam B, Panna T. Taste masking and formulation of ondansetron hydrochloride mouth dissolving tablets. Int J Pharm Sci Res 2015;6:856-64.

35. Remya PN, Damodharan N, Lokendra S. Formulation and evaluation of fast disintegrating orodispersible tablets of ondansetron hydrochloride. J Pharm Sci Res 2012;4:1810-3.

36. Ved P, Saurabh M, Shiv KY, Hemlata, Vikas J. Fast disintergrating tablets: opportunity in drug delivery system. J Adv Pharm Technol Res 2011;2:223-35.

37. Nehal S, Garima G, Pramod KS. Fast dissolving tablets: preperation, characterization and evaluation: an overview. Int J Pharm Sci Rev Res 2015;4:87-96. 